\title{
Evaluation of a new test system for rubella haemagglutination inhibiting antibodies
}

\author{
PAUL C. ROBERTS AND SANDRA J. HOBBS
}

From the Public Health Laboratory, Myrtle Road, Kingsdown, Bristol BS2 8EL, UK

SUMMARY A recently available kit for the determination of rubella haemagglutination inhibiting antibodies (Rubindex, Ortho Diagnostics) was compared with the method used routinely in this laboratory. Rubindex compared favourably in that no significant difference in titre was found in $95.1 \%$ of 287 sera tested. Difficulty occurred with some sera from cases of Mycoplasma pneumoniae infection, rheumatoid arthritis, and a small number of normal sera containing human ' $O$ ' cell agglutinins. This was overcome by treatment of the sera with 2-mercaptoethanol. Rubindex had the advantage that all reagents were provided in kit form and the trypsinised human ' $O$ ' cells provided had a longer shelf life than chick erythrocytes.

Since the original description of the rubella haemagglutination inhibition (HAI) test by Stewart et al. (1967) this test and minor modifications of it have formed the basis for the routine serological estimation of rubella antibodies.

The HAI test has formed an increasing part of the work load of most virus laboratories in the diagnosis of recent and past rubella infection. The detection of susceptible women of childbearing age is of particular importance since the advent of rubella vaccination.

Erythrocytes from pigeons and 1-day-old chicks were found to be the most suitable for the rubella HAI test (Halonen et al., 1967; Holmes and Warburton, 1967; Stewart et al., 1967). More recently, trypsinised human ' $O$ ' cells have been shown to be at least as sensitive as, or more sensitive than, 1-day-old chick erythrocytes (Biddle, 1971; Quirin et al., 1972; Bannerman and Ross, 1973; Nelson et al., 1974; Iwakata et al., 1974).

Ortho Diagnostics have recently introduced a rubella HAI test (Rubindex) in kit form which utilises trypsinised human ' $O$ ' cells as indicator erythrocytes. This paper compares the Rubindex rubella HAI test with our routine method, utilising day-old chick erythrocytes, for reproducibility, sensitivity, and speed of testing.

Received for publication 19 April 1977
Material and methods

STANDARD METHOD

Test sera

Category 1: 310 sera received at this laboratory for rubella antibody estimation between June 1975 and September 1975; 257 of these were from antenatal women, 41 were from medical students, six were from recent cases of Mycoplasma pneumoniae infection, and six were known to contain rheumatoid factor. The sera from antenatal patients were freshly received. All other sera had been stored at $-20^{\circ} \mathrm{C}$ before testing.

Category 2: 50 sera previously found to have no antibody on routine testing. These sera had been stored at $-20^{\circ} \mathrm{C}$.

Category 3: six sera used for detection of rubellaspecific IgM. These sera were from patients known to have had a rubella rash 7-18 days before blood was taken. Infection was confirmed by rising antibody level.

\section{Serum pre-treatment}

$0.3 \mathrm{ml}$ of serum was added to $0.9 \mathrm{ml}$ of $25 \%$ acidwashed kaolin at pH 9.0 (Schmidt and Lennette, 1970). The tubes were rotated on a roller drum for one hour at room temperature (RT) at 8 revolutions per hour and centrifuged at $1500 \mathrm{~g}$ for 20 minutes at 
Table Comparison of titres obtained by Rubindex and by the standard method

\begin{tabular}{lrr}
\hline & No. & $\%$ \\
\hline Total no. of sera tested & 403 & \\
Total no. of sera comparable & 287 & \\
No. of sera with same titre ( \pm 2-fold) & 273 & $95 \cdot 1$ \\
No. of sera with titre 4-fold higher with Rubindex & 2 & $0 \cdot 7$ \\
No. of sera with titre > 4-fold higher with Rubindex & 0 & 0 \\
No. of sera with titre 4-fold lower with Rubindex & 7 & $2 \cdot 4$ \\
Nol of sera with titre $>$ 4-fold lower with Rubindex & 5 & $1 \cdot 7$
\end{tabular}

Therefore no significant difference in $95.1 \%$ of comparable sera

$4^{\circ} \mathrm{C}$. The treated sera were left overnight at $4^{\circ} \mathrm{C}$. Before testing $0.05 \mathrm{ml}$ of $0.5 \mathrm{M}$ 2-mercaptoethanol (2-ME) was added to each tube and the tubes were incubated at $37^{\circ} \mathrm{C}$ in a waterbath for 1 hour. The treated serum was regarded as being at a dilution of $1: 4$.

\section{Cells and diluent}

As used in the method of Stewart et al. (1967).

\section{Antigen}

Rubella haemagglutinin was obtained from the Central Public Health Laboratory as a freeze-dried antigen prepared in baby hamster kidney cells. Each $1 \mathrm{ml}$ ampoule of antigen was reconstituted in $1 \mathrm{ml}$ distilled water and diluted for use in Dextrose Gelatin Veronal buffer (DGV) with $0.2 \%$ bovine plasma albumin (BPA). Four to eight haemagglutinating units (HAU) were used in the tests and fresh antigen was prepared each day.

\section{RUBINDEX METHOD}

Four kits of 100 tests per kit were used for the study, taken from two separate batches.

\section{Test sera}

Categories 1, 2, and 3: As described for standard method.

Category 4: 43 additional routine sera tested with and without added 2-ME, to determine its effect on total immunoglobulin titres.

\section{Serum pre-treatment}

$0.1 \mathrm{ml}$ serum, $0.2 \mathrm{ml}$ Rubindex ${ }^{1}$ diluent, and $0.1 \mathrm{ml}$ Rubindex manganous chloride/heparin solution were mixed gently together. The manganous chloride and heparin are supplied separately in the kit and are mixed on a 1: 1 basis immediately before use. The sera were incubated at $4^{\circ} \mathrm{C}$ for 30 minutes, $0.4 \mathrm{ml}$ Rubindex diluent was added to each tube, and the tubes were gently shaken and then centrifuged at $1500 \mathrm{~g}$ for 15 minutes at $4^{\circ} \mathrm{C}$. The supernatant was pipetted into a labelled stoppered tube and was considered to be at a serum dilution of $1: 8$. In this study all sera were tested either on the same day as, ${ }^{1}$ Standard HEPES saline albumin gelatin buffer (Ortho Diagnostics) or on the day following, adsorption. Sera were stored overnight at $4^{\circ} \mathrm{C}$ when necessary.

Cells

Trypsinised human group $\mathrm{O} \mathrm{Rh}$ negative erythrocytes were used. These were supplied as a $4 \%$ suspension and were diluted for use to a concentration of $0.25 \%$ in Rubindex diluent.

\section{Diluent}

Supplied in the Rubindex kit.

\section{Antigen}

Supplied in liquid form and used at the specified dilution of 1:16. A fresh aliquot was diluted with Rubindex diluent on each occasion it was used.

\section{Equipment}

V-bottomed microtitration plates and microdiluters (Cooke Engineering Incorporated) were used for both systems.

\section{TEST PROCEDURES}

\section{Standard method}

The method of Stewart et al. (1967) was used except 8 that serum/antigen mixtures were incubated at RT? for 1 hour instead of at $36^{\circ} \mathrm{C}$ for 15 minutes. Controls: Positive and negative controls, serum and cell controls, and an antigen back-titration were incorporated in each batch of tests.

\section{Rubindex method}

Serial two-fold dilutions of serum were made in Rubindex diluent using $0.025 \mathrm{ml}$ volumes. One volume containing 4-8 HAU of antigen was added and the tests were incubated at $4^{\circ} \mathrm{C}$ for 1 hour. Two volumes of $0.25 \%$ indicator erythrocytes were added and the tests were incubated at RT for $1 \frac{1}{2}$ hours. The highest dilution of serum showing complete inhibition of agglutination was taken as the end point of titration, as in the standard method.

Controls: High and low positive control sera and a negative control serum are provided in the kit and were incorporated in each batch of tests. Serum and cell controls and an antigen back-titration were also incorporated.

Category 4 sera were pre-treated in the same manner as sera in other categories. Immediately before testing they were treated with $2-\mathrm{ME}$, as described in the standard method.

\section{Rubella-specific IgM}

Six sera from convalescent cases of rubella were adsorbed with chick erythrocytes and group $\mathbf{O}$ human erythrocytes and tested by both methods after 
sucrose density gradient centrifugation (Caul et al., 1974).

\section{Results}

Of 403 routine sera tested, four were excluded from the results because titres were greater than 256 in one method and less than 256 in the other. There was insufficient serum to repeat these tests. Thirteen sera had titres greater than 256 by both methods and were not included as there were no comparable endpoints to the titrations. Three sera from $\mathrm{Myco}$ plasma pneumoniae infections and three sera containing rheumatoid factor were excluded because they contained ' $O$ ' cell agglutinins of sufficient strength to interfere with the reading of Rubindex titres. It was later found that both these agglutinins and the agglutinins occasionally present in normal human sera could be readily removed by treatment with 2-ME, as used in the standard method. Fortythree additional sera (category 4) were tested by the Rubindex method with and without 2-ME to ascertain whether or not its use affected the titres. No significant difference ( $>$ two-fold) was observed. Fifty sera previously shown to contain no antibody by the standard method were repeated by both methods and all had titres of less than 1:8. The category 4 sera and the 50 negative sera were not included in the total of comparable results.

Of the 14 sera showing a four-fold or greater difference in titre between the two methods, eight were repeated at a later date, the other six being insufficient to re-test. When repeated, there was a variation in the titre from the original result in both methods. Six had identical titres by both methods and two had titres two-fold higher by Rubindex.

There was no significant difference in titre ( $>$ twofold) between the two methods in $95.1 \%$ of 287 comparable routine sera.

Six sera were tested for the presence of rubellaspecific IgM after sucrose density gradient centrifugation. One of these contained ' $O$ ' cell agglutinins of sufficient strength to interfere with the reading of Rubindex results. Of the five comparable sera, two had an identical titre by both methods and three were two-fold lower using Rubindex. 2-ME was used in both methods to confirm that the antibody present was immunoglobulin class $\mathbf{M}$. There was at least a six-fold drop in titre after 2-ME treatment in both methods.

\section{Discussion}

The use of kits in many fields of diagnostic laboratory work is increasing. Rubindex is a new addition to the range of kits available. When used in parallel with the standard method employed by this laboratory there was good correlation in titres between the two methods. The Rubindex system does have several advantages. Firstly, all reagents are standardised as a system, thereby giving a high degree of consistency. Secondly, the trypsinised human erythrocytes provided are stable for four weeks as opposed to a maximum of a few days for chick erythrocytes. They are provided ready for dilution.

A high proportion of the sera tested from cases of rheumatoid arthritis and from recent infections with Mycoplasma pneumoniae gave rise to non-specific haemagglutination in the Rubindex system. A few normal human sera produced a similar result. As some Mycoplasma pneumoniae infections and early rheumatoid conditions can clinically resemble rubella this can be of importance. The problem was overcome by the addition of $0.05 \mathrm{ml} 0.5 \mathrm{M} \mathrm{2-mercapto-}$ ethanol. This method of removing non-specific agglutinins of immunoglobulin class $M$ has been in use in this laboratory for several years, and a similar method has been described by Mortimer (1976). The extra procedure was found to be very worthwhile in that it facilitated the reading of titres of a number of sera which would otherwise have been impossible. The addition of 2-ME had no significant effect on the titres obtained. Treatment with 2-ME would inactivate any rubella-specific IgM present in sera from recent rubella infections, but, in practice, a further specimen of serum would be requested in all such cases and a rise in titre obtained. This method of removing class $M$ immunoglobulins with 2-ME treatment is an improvement on the method used by Smith and Cummins (1976). It is more effective than adsorption with strong suspensions of indicator cells and also, in our standard method, avoids the possibility of introducing non-specific inhibitors from chick erythrocytes used in pre-adsorption of sera (Saeed and Murray, 1975).

The Rubindex system was used to detect rubellaspecific IgM in six human sera after sucrose density gradient centrifugation. Despite pre-adsorption with human ' $O$ ' cells, one of these sera contained sufficient ' $O$ ' cell agglutinins to cause difficulty in reading. Rubindex detected IgM in the remaining five sera, with sensitivity equal to that of our standard method.

In conclusion, the Rubindex system was found to be reliable and reproducible and took slightly less time in serum pre-treatment than the standard method. We found little difference in sensitivity between the two methods. The kit form should make the system particularly welcome in smaller laboratories with limited time and facilities for preparing the reagents used in other methods. 
We thank Mr E. O. Caul for helpful advice throughout the study and preparation of this paper. We also thank Dr C. M. P. Bradstreet of the Central Public Health Laboratory, Colindale, for providing antigen.

\section{References}

Bannerman, C. M., and Ross, C. A. C. (1973). Trypsintreated human erythrocytes for rubella haemagglutination inhibition tests. Journal of Clinical Pathology, 26, 807-808.

Biddle, F. (1971). The unmasking of receptors for rubella virus by trypsinisation of red cells. Microbios, 3, 255-260.

Caul, E. O., Smyth, G. W., and Clarke, S. K. R. (1974). A simplified method for the detection of rubella-specific IgM employing sucrose density fractionation and 2-mercaptoethanol. Journal of Hygiene, 73, 329-340.

Halonen, P. E., Ryan, J. M., and Stewart, J. A. (1967). Rubella haemagglutinin prepared with alkaline extraction of virus grown in suspension cultures of BHK-21 cells. Proceedings of the Society for Experimental Biology and Medicine, 125, 162-167.

Holmes, I. H., and Warburton, M. F. (1967). Is rubella an arbovirus? Lancet, 2, 1233-1236.

Iwakata, S., Morrissey, L. P., Rhodes, A. J., and Labzoffsky, N. A. (1974). The use of trypsin-treated human group $\mathbf{O}$ erythrocytes in the rubella hemag- glutination inhibition test. Archiv für die Gesamte Virusforschung, 45, 352-361.

Mortimer, P. P. (1976). An alternative method for inactivating heteroagglutinins in human sera applicable to rubella haemagglutination inhibition testing at low dilutions. Journal of Clinical Pathology, 29, 417-422.

Nelson, D. B., Quirin, E. P., and Inhorn, S. L. (1974). Compatibility of trypsin-modified human erythrocytes in the rubella haemagglutination-inhibition test employing three serum treatment procedures. Applied Microbiology, 27, 767-770.

Quirin, E. P., Nelson, D. B., and Inhorn, S. L. (1972). Use of trypsin-modified human erythrocytes in rubella hemagglutination-inhibition testing. Applied Microbiology, 24, 353-357.

Saeed, A. A., and Murray, H. G. S. (1975). A non-specific inhibitor of rubella haemagglutinin in day-old chick cells (Letter). Lancet, 2, 413-414.

Schmidt, N. J., and Lennette, E. H. (1970). Variables of the rubella hemagglutination-inhibition test system and their effect on antigen and antibody titres. Applied Microbiology, 19, 491-504.

Smith, J. A., and Cummins, A. C. (1976). Evaluation of a rubella hemagglutination inhibition test system. Journal of Clinical Microbiology, 3, 5-7.

Stewart, G. L., Parkman, P. D., Hopps, H. E., Douglas, R. D., Hamilton, J. P., and Meyer, H. M., Jr. (1967). Rubella-virus hemagglutination-inhibition test. New England Journal of Medicine, 276, 554-557. 